\title{
Clinical pharmacology of aminocaproic and tranexamic acids
}

\author{
INGA MARIE NILSSON \\ From the Coagulation Laboratory, University of Lund, Allmänna Sjukhuset, Malmö, Sweden
}

In a systematic search for a substance with antifibrinolytic properties Okamoto and his group in Japan found that several mercapto- and aminocarbonic acids were active. Of these substances epsilon-aminocaproic acid (EACA) had the strongest antifibrinolytic effect. ${ }^{12}$ The Japanese workers described it as a plasmin inhibitor in vitro and useful in inhibiting proteolytic enzymes in vivo. They gave EACA in a dose of $10-20 \mathrm{~g}$ a day by mouth or intravenously to over 100 patients and observed no toxic effects. Their investigation did not include any metabolic studies. EACA has since been widely used and its mode of action and pharmacokinetics intensively studied.

In a continued search for more potent antifibrinolytic components p-aminomethyl cyclohexane arboxylic acid (AMCHA) was found to be more potent than EACA. ${ }^{3}$ This compound contains two stereoisomers. Independently Melander et al. $^{4}$ and Okamoto et al. ${ }^{5}$ found that only the trans-form was antifibrinolytically active. The antifibrinolytically active form was called tranexamic acid (AMCA). It is 6-10 times stronger than EACA and is now used more widely. Its pharmacokinetics have been the subject of several studies. This paper surveys the pharmacology and toxicology of EACA and AMCA.

\section{Pharmacokinetics}

\section{AMINOCAPROIC ACID (EACA)}

The absorption, distribution, and excretion of EACA given intravenously and by mouth have been studied in man. ${ }^{6-8}$ High-voltage electrophoresis and plasma amino-acid chromatography with ion exchange resin loaded paper were used for assaying EACA in plasma, serum, urine, and tissues. ${ }^{7-9}$ The blood was assayed for fibrinolytic activity by measuring the plasma euglobulin clot lysis time and/or the activity of plasma and of resuspended euglobulin precipitate on unheated and heated fibrin plates. The urokinase activity of urine was assayed by a clot lysis method or by a fibrin plate technique in which the results are expressed in arbitrary urokinase units by reference to a standard urokinase preparation..$^{1011}$

Intravenous administration of $10 \mathrm{~g}$ EACA or $100 \mathrm{mg} \mathrm{EACA} / \mathrm{kg}$ bodyweight produces an initial serum concentration of about $150 \mathrm{mg} / 100 \mathrm{ml}$ which falls to $3.5 \mathrm{mg} / 100 \mathrm{ml}$ within $3-4$ hours (Fig. 1). The biological half life was calculated to be about 77 minutes. Andersson et al. ${ }^{8}$ found that about $70 \%$ of the dose given intravenously was excreted in the urine within 24 hours (Fig. 2). McNicol et al. ${ }^{7}$ found $80-100 \%$ of the given dose in the urine within 4-6 hours. The EACA is thus concentrated

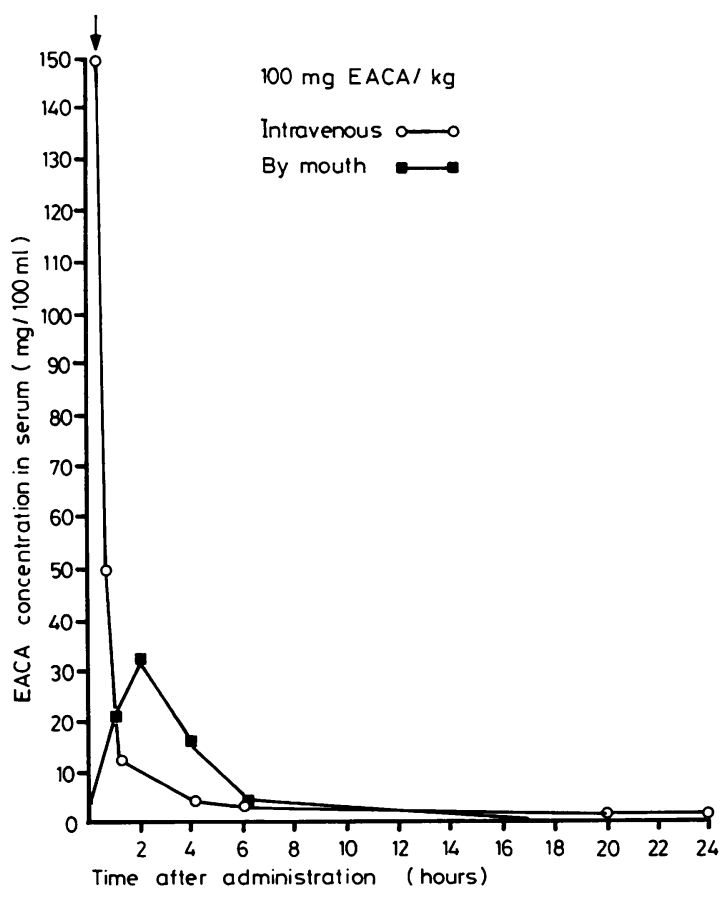

Fig. 1 Concentration of EACA $(\mathrm{mg} / 100 \mathrm{ml})$ in serum after a dose of $100 \mathrm{mg} / \mathrm{kg}$ bodyweight intravenously or by mouth. 

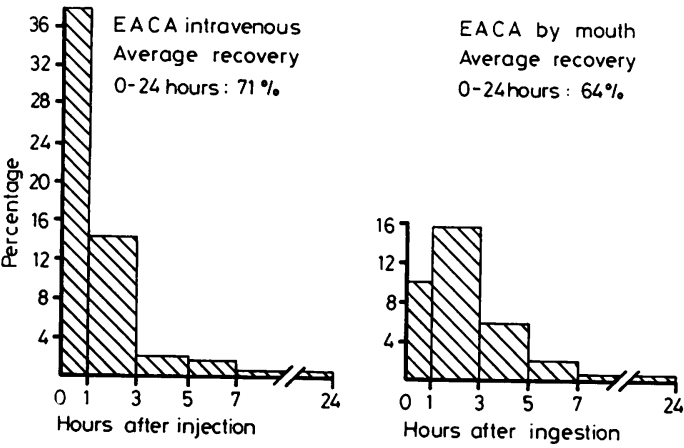

Fig. 2 Urinary recovery of EACA in four men volunteers after receiving $100 \mathrm{mg} / \mathrm{kg}$ bodyweight intravenously or by mouth.

many times during excretion, urinary levels being 50 to 100 times those found in plasma. McNicol et al. ${ }^{7}$ measured the renal clearance rates of EACA in healthy volunteers at a time when their plasma EACA concentrations were stable (that is, they had received repeated doses of EACA). Simultaneously endogeneous creatinine clearance rates were also measured. EACA clearances when the plasma concentrations were in the range of 14 to $19 \mathrm{mg} / 100$ $\mathrm{ml}$ varied from 65 to $92 \%$ of the creatinine clearance. These findings indicated that the kidney handled EACA primarily by filtration.

EACA given by mouth is rapidly absorbed, almost entirely from the gastrointestinal tract. After $100 \mathrm{mg} / \mathrm{kg}$ bodyweight by mouth the peak plasma concentration of EACA was $30 \mathrm{mg} / 100 \mathrm{ml}$ two to three hours after ingestion (Fig. 1). At four hours it was $16 \mathrm{mg} / 100 \mathrm{ml}$ compared with 3.9 $\mathrm{mg} / 100 \mathrm{ml}$ four hours after intravenous injection. After six hours the concentration was similar to that found after intravenous administration. Renal excretion differed from that found after intravenous injection (Fig. 2). Only $10 \%$ of the dose had been excreted within one hour, and $25 \%$ within three hours. The 24-hour urinary recovery after the oral administration was $64 \%$. The figure given by $\mathrm{McNicol}$ et al. ${ }^{7}$ is somewhat higher-namely, $78 \%$.

EACA enters human red cells and various tissues. ${ }^{78}$ It appears to move in and out of the cells according to the extracellular concentration. It is quite clear that the major portion of EACA is not metabolised in vivo. Since not all of the EACA was recovered in the urine a small portion may be actively metabolised.

In-vitro experiments and clinical experience indicate that a plasma EACA concentration of at least about $13 \mathrm{mg} / 100 \mathrm{ml}$ is required to control systemic fibrinolytic activity. ${ }^{6} 712$ Since EACA is rapidly excreted in the urine it must be given intravenously at short intervals to maintain a therapeutic level. Nilsson et al. ${ }^{12}$ recommended a dose of $0.1 \mathrm{~g} / \mathrm{kg}$ bodyweight every 3-4 hours. $\mathrm{McNicol}$ et al. ${ }^{7}$ recommended an initial loading dose of $10 \mathrm{~g}$ followed by a continuous intravenous infusion of $1 \mathrm{~g} /$ hour to keep a steady plasma concentration of about $13 \mathrm{mg} / 100 \mathrm{ml}$. With these doses it has also been possible to inhibit the fibrinolytic activity induced by infusion of streptokinase. A therapeutic concentration can also be maintained by giving $0 \cdot 1 \mathrm{~g} / \mathrm{kg}$ bodyweight every $4-6$ hours. ${ }^{6} 12$

To inhibit the urokinase activity in the urine EACA has to be present in the urine in a concentration of about $0.1 \mathrm{~mol} / \mathrm{l}$-that is, 10 times higher than that needed to inhibit systemic fibrinolysis in plasma. But since the drug is greatly concentrated during excretion, the urinary concentrations being 50 to 100 times those in plasma, effective concentrations of urinary EACA can be achieved by giving smaller doses, which have only a slight systemic effect. Thus a dose of $3 \mathrm{~g}$ EACA three times a day is sufficient to inhibit the local fibrinolytic activity in the urinary tract. ${ }^{12}$

TRANEXAMIC ACID (AMCA)

Andersson et al. ${ }^{813}$ first studied the absorption, distribution, and excretion of AMCA given intravenously and by mouth in man. They measured the acid in serum with a biological method as well as with high-voltage paper electrophoresis. AMCA in urine was measured by high-voltage paper electrophoresis. After intravenous administration of $10 \mathrm{mg}$ AMCA $/ \mathrm{kg}$ bodyweight the serum concentration was 18,10 , and $5 \mu \mathrm{g} / \mathrm{ml}$ after 1,3 , and 5 hours, respectively (Fig. 3). The biological half life was calculated to be about 80 hours. About $30 \%$ was recovered in the urine during the first hour, $55 \%$ during the first three hours, and about $90 \%$ within 24 hours (Fig. 4).

After AMCA $10 \mathrm{mg} / \mathrm{kg}$ bodyweight by mouth the maximum serum concentration was only about $2 \mu \mathrm{g} / \mathrm{ml}$ after three hours. After $100 \mathrm{mg} / \mathrm{kg}$ by mouth a plasma concentration of $40 \mu \mathrm{g} / \mathrm{ml}$ was reached within four hours (Fig. 3). Thus AMCA is not absorbed from the gastrointestinal tract so effectively as EACA. About $40 \%$ of an oral dose of $10-15 \mathrm{mg} / \mathrm{kg}$ was recovered in the urine within 24 hours (Fig. 4). Similar results have been reported by Kaller. ${ }^{14}$

More recently Eriksson et al. ${ }^{15}$ have investigated the pharmacokinetics of AMCA. Two healthy volunteers received $1 \mathrm{~g} \mathrm{AMCA}$ intravenously. The concentration of AMCA in plasma and urine was measured by a method using high-voltage electrophoresis. The plasma concentration curve (Fig. 5) showed three monoexponential decays. The first was 


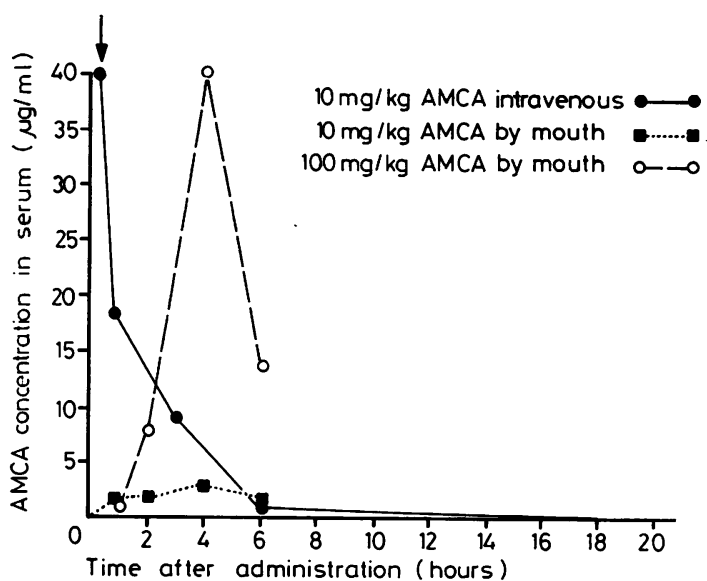

Fig. 3 Concentration of $A M C A(\mu \mathrm{g} / \mathrm{ml})$ in serum after various doses intravenously or by mouth.
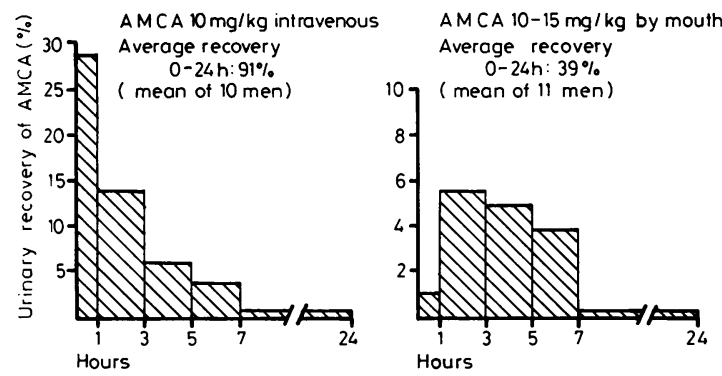

Fig. 4 Urinary recovery of AMCA in 10 men volunteers after a single intravenous injection of $10 \mathrm{mg} / \mathrm{kg}$ bodyweight and in 11 men after a single dose by mouth of $10-15 \mathrm{mg} / \mathrm{kg}$.
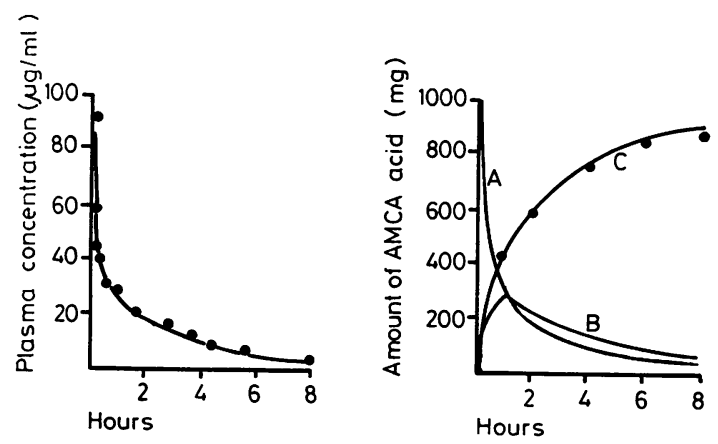

Fig. 5 Left. Plasma concentration of AMCA $(\mu \mathrm{g} / \mathrm{ml})$ after single intravenous dose of $1 \mathrm{~g}$. Right. Calculated amounts of AMCA after single intravenous dose of $1 \mathrm{~g}$. A. Amount in central compartment. B. Amount in tissue compartment. C. Amount excreted in urine. (०- Urinary excretion, experimental points. (From Eriksson et al. ${ }^{15}$ by permission of the Editor, European Journal of Clinical Pharmacology.) a very rapid one, the second had a half life of 1.3-2 hours, and the third a half life of 9-18 hours. About half of the dose was recovered unchanged in the urine during the first $3-4$ hours, $90-95 \%$ within 24 hours, and $95-99 \%$ within $48-72$ hours. ${ }^{16}$ Fig. 5 also shows the calculated amounts of AMCA in the central and tissue compartments at various times and the amounts eliminated. The elimination half life was about one-fourth of the disposition half life. ${ }^{15}$ This was owing to the distribution of AMCA in the tissue compartment, which makes it partly unavailable for elimination. The uncorrected plasma clearance rate was $110-115 \mathrm{ml} / \mathrm{min}$, which, corrected for an average plasma protein binding of $15 \%$, approximately equalled the glomerular filtration. This indicates that AMCA is eliminated by glomerular filtration and that neither tubular excretion nor absorption takes place.

Impairment of renal function prolongs the biological half life of AMCA. Thus in patients with serum creatinine concentrations of $>500 \mu \mathrm{mol} / 1$ $(5.6 \mathrm{mg} / 100 \mathrm{ml})$ the half life was 24 to 48 hours. ${ }^{17}$ Vessman and Strömberg ${ }^{18}$ have developed a rapid gas chromatographic method for measuring AMCA in small biological samples. The lower limit of detection is $40 \mathrm{pg} / \mathrm{ml}$. They studied the plasma concentration of AMCA after giving $0.5 \mathrm{~g}$ and $2.0 \mathrm{~g}$ by mouth. Peak concentrations of about 5 and $15 \mu \mathrm{g} / \mathrm{ml}$, respectively, were noted within $2-4$ hours. After 12 hours the concentration was less than $1 \mu \mathrm{g} / \mathrm{ml}$.

Like EACA, AMCA is widely distributed throughout the extracellular and intracellular compartments. AMCA $1 \mathrm{~g}$ given 4-hourly intravenously to patients with subarachnoid haemorrhage enters the cerebrospinal fluid at a concentration of about 2-5 $\mu \mathrm{g} / \mathrm{ml} .{ }^{19}$ Ahlberg et al. ${ }^{20}$ gave $10 \mathrm{mg}$ AMCA $/ \mathrm{kg}$ bodyweight to patients before knee joint operations. They found that AMCA rapidly diffused into the joint fluid and synovial membranes and reached the same concentration in the joint fluid as in the serum. The biological half life in the joint fluid was about 3 hours. Bramsen ${ }^{21}$ has investigated the aqueous humour concentration of AMCA after oral administration of the drug. On a dose of $25 \mathrm{mg} \mathrm{AMCA} / \mathrm{kg}$ bodyweight three times a day the concentration within three hours was $1.6 \mu \mathrm{g} / \mathrm{ml}$ compared with a serum concentration of $15 \mu \mathrm{g} / \mathrm{ml}$. The AMCA disappeared slowly from the aqueous humour.

Given by mouth or intravenously AMCA diffuses into semen and inhibits its normally high fibrinolytic activity. AMCA has no effect on the motility of spermatozoa. ${ }^{22}$ AMCA passes transplacentally to the fetus. ${ }^{23}$ After intravenous injection of $10 \mathrm{mg} / \mathrm{kg}$ bodyweight the concentration in the fetal serum may be anything between 4 and 31 
$\mu \mathrm{g} / \mathrm{ml}$. Tranexamic acid can be found in the milk of lactating women given AMCA (Eriksson, personal communication), but the concentration is very low and is about $1 / 100$ of that in the maternal plasma.

AMCA and EACA are distributed among various tissues. The tissues contain plasminogen activators, which the antifibrinolytic drugs inhibit. ${ }^{8}$ 2425 Normal tissue activators most probably do not induce but rather sustain bleeding, since they dissolve the small clots sealing opened vessels and essential for the first stage of wound healing. In treating local fibrinolysis due to the action of tissue activators it is important to know which concentrations of the drugs are required and also how long the fibrinolytic inhibitor persists in different tissues. Andersson et al. ${ }^{8}$ studied the fibrinolytic activity of various tissue extracts obtained at operation in the presence of increasing concentrations of AMCA and EACA. A 98-100\% reduction of the tissue activator activity required the presence of AMCA in a concentration of about $100 \mu \mathrm{g} / \mathrm{ml}$. The corresponding concentration for EACA was $1000 \mu \mathrm{g} / \mathrm{ml}$. An $80 \%$ inhibition required $100 \mu \mathrm{g} / \mathrm{ml}$ of EACA or $10 \mu \mathrm{g} / \mathrm{ml}$ of AMCA. Judging from clinical experience an $80 \%$ inhibition is sufficient to suppress the activity.

Andersson et al. ${ }^{8}$ measured the fibrinolytic activity and the concentration of AMCA and EACA in serum and in pieces of human tissue (colon, kidneys, prostate) obtained at operation. The fibrinolytic activity of homogenates of the tissues was measured on unheated fibrin plates and the concentration of AMCA and EACA with highvoltage electrophoresis. AMCA was given 36-48 hours before the operation in four doses of about $10-20 \mathrm{mg} / \mathrm{kg}$ bodyweight each. The corresponding dose of EACA was $100 \mathrm{mg} / \mathrm{kg}$. The last dose was given at various intervals before operation. The results showed that the antifibrinolytically active concentration of AMCA $(10 \mu \mathrm{g} / \mathrm{ml})$ persisted longer in the tissues examined than did the corresponding concentration of EACA $(100 \mu \mathrm{g} / \mathrm{ml})$. AMCA thus has not only a higher fibrinolytic activity than EACA but it also persists longer in the tissues. After repeated intravenous or oral doses of AMCA $(10 \mathrm{mg} / \mathrm{kg}$ intravenously 4-5 times a day or $20 \mathrm{mg} / \mathrm{kg}$ by mouth 3-4 times a day) an adequate antifibrinolytic activity in tissues can be maintained for up to 17 hours without any further dose. Risberg $^{26}$ found a retention of AMCA in the lung tissue in rats.

Judging from in-vitro experiments and clinical experience control of systemic fibrinolysis requires a plasma AMCA concentration of about 10-15 $\mu \mathrm{g} / \mathrm{ml}$. Since the drug is rapidly excreted in the urine it must, like EACA, be given intravenously at short intervals to maintain a therapeutic level. Andersson et al. ${ }^{13}$ recommended a dose of 10 $\mathrm{mg} / \mathrm{kg}$ bodyweight every 3-4 hours. AMCA is not so readily absorbed as EACA and therefore when given by mouth is only three times as active as EACA. An oral dose of about $30-40 \mathrm{mg} / \mathrm{kg}$ bodyweight every 4-5 hours should be optimal in treating conditions with generalised fibrinolysis. For inhibiting tissue activators - that is, in the treatment of conditions associated with local fibrinolysisAMCA has been recommended in a dose of about $20 \mathrm{mg} / \mathrm{kg} \mathrm{3-4} \mathrm{times} \mathrm{a} \mathrm{day.}$

Inhibition of urokinase activity in the urine requires an AMCA concentration of about 200 $\mu \mathrm{g} / \mathrm{ml}$. After AMCA by mouth in a dose of $10 \mathrm{mg} / \mathrm{kg}$ bodyweight the fibrinolytic activity of the urine is much reduced (Fig. 6). A dose of 1-2 g two to three times a day is sufficient to inhibit the urokinase activity in the urine. ${ }^{27}$

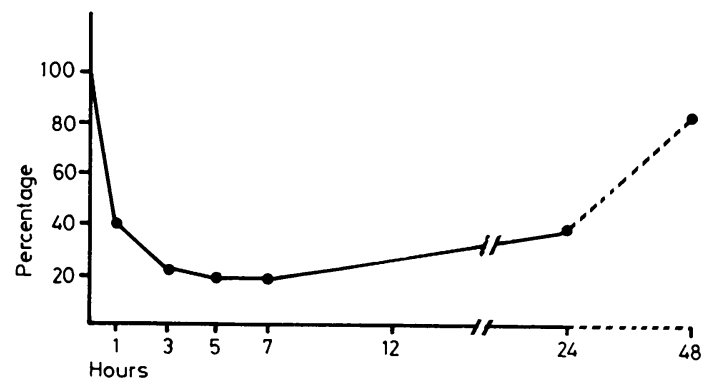

Fig. 6 Fibrinolytic activity of urine after AMCA 10 $\mathrm{mg} / \mathrm{kg}$ bodyweight by mouth.

\section{Toxicology}

Both EACA and AMCA are of low acute toxicity. ${ }^{4}$ No fetal abnormalities have been found in teratogenic studies in rats, rabbits, and mice given AMCA in doses of up to $5000 \mu \mathrm{g} / \mathrm{kg}$ a day. Retinal changes have been reported in dogs after receiving AMCA by mouth over a period of one year in doses approximately seven times higher than the maximum recommended daily dose for man. No such changes were seen in dogs given for a year three and a half times the maximal oral dose per $\mathrm{kg}$ bodyweight recommended for man, in rats given seven times the maximal human dose for 22 months, or monkeys that had been given 18 times the maximal intravenous dose for 14 days. ${ }^{28}$ Neither were any retinal changes seen in patients treated with AMCA for months or years (Pandolfi, personal communication). In patients to be treated continuously for several weeks, however, visual acuity, colour perception, the ocular fundi, and fields of vision should be reviewed. 
Adenoma and adenocarcinoma of the liver have been reported in rats after 22 months' oral treatment with about 27 times the maximum dose of AMCA $/ \mathbf{k g}$ bodyweight recommended for man, but not after 12 months' treatment. No such tumours have been seen in rats given six times the maximum daily dose per $\mathrm{kg}$ bodyweight recommended for human beings. ${ }^{28}$

Carroll and Tice ${ }^{29}$ found that doses of 0.3 to $1.4 \mathrm{~g}$ of EACA $/ \mathrm{kg}$ given intravenously to nephrectomised dogs produced hyperpotassaemia. They believed that EACA is taken up by muscle cells and thereby increases the escape of intracellular $\mathrm{K}^{+}$. Muscle pain with increases in the serum enzymes, creatinine phosphokinase, and aldolase have been reported in clinical investigations of EACA in patients with hereditary angioneurotic oedema. ${ }^{30}$ In one case Korsan-Bengtsen et al. ${ }^{31}$ found Zenker's hyaline degeneration in muscle cells in a muscle biopsy specimen. Wysenbeek et al. ${ }^{32}$ have recently reported a patient who developed an acute delirious state after EACA administration. No residual psychiatric or neurological symptoms were observed. The side effect was thought to be related to the antifibrinolytic effect of the drug since a similar reaction has been reported with another antifibrinolytic drug, Trasylol, which acts completely differently to EACA.

EACA given to dogs and female rats in large doses has resulted in a $50 \%$ reduction of fertility but this was reversible. ${ }^{33}$ EACA and AMCA, though less often, may cause nausea, diarrhoea, nasal stuffiness, and conjunctival suffusion. Occasionally EACA produces orthostatic symptoms; AMCA does so only rarely. A fall in blood pressure has been reported in a few cases after administration of AMCA. ${ }^{34} 35$

An important question is whether treatment with EACA or AMCA predisposes to thrombosis and intravascular coagulation. There are isolated reports of arterial or venous thrombosis associated with EACA therapy, but in each case a disease known to predispose to thrombosis has also been present. ${ }^{11} 36$ Furthermore, Rydin and Lundberg ${ }^{37}$ have reported two patients receiving AMCA to control menorrhagia and Davies and Howell ${ }^{38}$ one patient treated with AMCA for hereditary angio-oedema who developed intracranial arterial thrombosis. Detailed studies using phlebography ${ }^{39}$ or ${ }^{125}$ I-fibrinogen uptake $^{40}$ have shown no change in the incidence of venous thrombosis attributable to treatment with EACA after prostatectomy.

In a double-blind multicentre study of 515 patients untreated or treated with EACA the mortality due to pulmonary embolism and myocardial infarction was largely similar in both groups. ${ }^{41}$ Hedlund ${ }^{42}$ reported the incidence of thrombosis as detected by the 125I fibrinogen uptake test in 201 prostatectomy patients, 100 of whom had taken $1 \mathrm{~g}$ AMCA three times a day and 101 a placebo. There was no statistically significant difference in the incidence of thrombosis between the two groups. In tissue cultures of human veins the activator content is unaffected by culture in media containing AMCA $(1 \mathrm{mg} / \mathrm{ml}) .^{43}$ On the other hand, there is no doubt that EACA and AMCA can perpetuate existing fibrin deposits. ${ }^{44} 45$ Saldeen $^{46}$ found that antifibrinolytic therapy causes persistent fibrin deposits in the lung.

\section{Conclusion}

EACA and AMCA are potent antifibrinolytic drugs. AMCA is 7-10 times more potent than EACA by in-vitro and in-vivo assay. The pharmakokinetics of the drugs are now known and rational dose regimens for treating systemic and local fibrinolysis have been worked out. The drugs have no serious side effects. There is no evidence that they predispose to thrombosis but they may perpetuate existing fibrin deposits.

The following dosages are recommended for various bleeding conditions.

Systemic fibrinolysis This relatively rare clinical condition requires EACA $100 \mathrm{mg} / \mathrm{kg}$ intravenously at about 3 hourly intervals. After the first injection EACA can be given by mouth. AMCA $10 \mathrm{mg} / \mathrm{kg}$ intravenously 3-4 hourly will give an adequate inhibitory plasma concentration. After an initial intravenous dose about $30-50 \mathrm{mg} / \mathrm{kg}$ by mouth may be given 3-4 hourly.

Local fibrinolytic bleedings For inhibiting tissue activators EACA $100 \mathrm{mg} / \mathrm{kg}$ intravenously or by mouth should by given three to four times a day. Owing to its sustained tissue activity AMCA 10-20 $\mathrm{mg} / \mathrm{kg}$ may be given by mouth three to four times daily.

Haematuria Urokinase activity in urine has been effectively inhibited by EACA $50 \mathrm{mg} / \mathrm{kg} 8$ hourly intravenously or by mouth. Judging from urinary excretion studies, AMCA $10 \mathrm{mg} / \mathrm{kg}$ intravenously or $20 \mathrm{mg} / \mathrm{kg}$ by mouth two to three times a day gives satisfactory results.

This investigation was supported by grants from the Swedish Medical Research Council (B8019X-00087-16C).

\section{References}

1 Okamoto S. Ref. to British Patent Specification 1957; 770,693 . 
2 Okamoto $\mathrm{S}$, et al. A suppressing effect of $\epsilon$-amino-ncaproic acid on the bleeding of dogs, produced with the activation of plasmin in the circulatory blood. Keio J Med 1959;8:247-66.

${ }^{3}$ Okamoto S, Okamoto U. Amino-methyl-cyclohexanecarboxylic acid: AMCHA. A new potent inhibitor of the fibrinolysis. Keio J Med 1962;11:105-15.

${ }^{4}$ Melander B, Gliniecki G, Granstrand B, Hanshoff G. The antifibrinolytically active isomer of AMCHA. Abstracts of the Xth International Congress of Haematology, Stockholm, Aug 30-Sept 4 1964:G68.

${ }^{5}$ Okamoto S, et al. Behaviour of tissue activators and the action of a series of potent inhibitors on fibrinolysis. Abstracts of the Xth International Congress of Haematology, Stockholm, Aug 30-Sept 4 1964: G65.

${ }^{6}$ Nilsson IM, Sjoerdsma A, Waldenström J. Antifibrinolytic activity and metabolism of $\epsilon$-aminocaproic acid in man. Lancet 1960;1:1322-6.

${ }^{7}$ McNicol GP, Fletcher AP, Alkjaersig N, Sherry S. The absorption, distribution, and excretion of $\epsilon$-aminocaproic acid following oral or intravenous administration to man. J Lab Clin Med 1962;59:15-24.

${ }^{8}$ Andersson L, Nilsson IM, Collen S, Granstrand B, Melander B. Role of urokinase and tissue activator in sustaining bleeding and the management thereof with EACA and AMCA. Ann NY Acad Sci 1968; 146:642-58.

${ }^{9}$ Sjoerdsma A, Hansson A. Determination of $\epsilon$-aminocaproic acid in urine by means of high-voltage paper electrophoresis. Acta Chem Scand 1969;13:2150-1.

${ }^{10} \mathrm{McNicol}$ GP, Fletcher AP, Alkjaersig N, Sherry S. The use of epsilon aminocaproic acid, a potent inhibitor of fibrinolytic activity, in the management of postoperative hematuria. J Urol 1961;86:829-37.

${ }^{11}$ Andersson L. Fibrinolytic states in prostatic disease and their treatment with epsilon-aminocaproic acid. Acta Chir Scand 1963;126:251-65.

${ }^{12}$ Nilsson IM, Andersson L, Björkman SE. Epsilonaminocaproic acid (E-ACA) as a therapeutic agent. Based on 5 years' clinical experience. Acta Med Scand (Suppl) 1966;448.

${ }^{13}$ Andersson L, Nilsson IM, Niléhn J-E, Hedner U, Granstrand B, Melander B. Experimental and clinical studies on AMCA, the antifibrinolytically active isomer of p-aminomethyl cyclohexane carboxylic acid. Scand J Haematol 1965;2:230-47.

${ }^{14}$ Kaller $H$. Enterale Resorption, Verteilung und Elimination von 4-Aminomethylcyclohexancarbonsäure (AMCHA) und $\epsilon$-Aminocapronsäure (ACS) beim Menschen. Naunyn Schmiederbergs Arch Pharmacol 1967;256:160-8.

${ }^{15}$ Eriksson O, Kjellman H, Pilbrant $\AA$, Schannong M. Pharmakokinetics of tranexamic acid after intravenous administration to normal volunteers. Eur $J$ Clin Pharmacol 1974;7:375-80.

${ }^{16} \mathrm{Kjellman} H$. Comments by the manufacturer of cyklokapron. In: Verstraete $\mathbf{M}$, ed. Haemostatic drugs. A critical appraisal. The Hague, Martinus Nijhoff Medical Division, 1977:140-1.

${ }^{17}$ Andersson L, Eriksson O, Hedlund PO, Kjellman H, Lindqvist B. Special considerations with regard to the dosage of tranexamic acid in patients with chronic renal diseases. Urol Res 1978;6:83-8.

${ }^{18}$ Vessman J, Strömberg S. Determination of tranexamic acid in biological material by electron capture gas chromatography after direct derivatization in an aqueous medium. Anal Chem 1977;49:369-73.

${ }^{19}$ Tovi D, Nilsson IM, Thulin C-A. Fibrinolysis and subarachnoid haemorrhage. Inhibitory effects of tranexamic acid. A clinical study. Acta Neurol Scand 1972;48:393-402.

${ }^{20}$ Ahlberg $\AA$, Eriksson O, Kjellman H. Diffusion of tranexamic acid to the joint. Acta Orthop Scand 1976; 47:486-8.

${ }^{21}$ Bramsen T. Effect of tranexamic acid on choroidal melanoma. Acta Ophthalmol 1978;56:264-9.

${ }^{22}$ Liedholm P, Åstedt B, Kullander S. Passage of tranexamic acid (AMCA) to semen in man and its effect on the fibrinolytic activity and on migration of spermatozoa. Fertil Steril 1973;24:517-20.

${ }^{23}$ Kullander S, Nilsson IM. Human placental transfer of an antifibrinolytic agent (AMCA). Acta Obstet Gynec Scand 1970;49:241-2.

${ }^{24}$ Nilsson IM. Local fibrinolysis as a mechanism for haemorrhage. Thromb Diathes Haemorrh 1975;34: 623-33.

${ }^{25}$ Thorsen S. Influence of fibrin on the effect of 6-aminohexanoic acid on fibrinolysis caused by tissue plasminogen activator or urokinase. In: Davidson JF, Rowan RM, Samama MM, Desnoyers PC, eds. Progress in chemical fibrinolysis and thrombolysis, vol 3. New York: Raven, 1978:269-83.

${ }^{26}$ Risberg B. Effect of tranexamic acid on pulmonary tissue fibrinolysis in the rat. Microvasc Res 1976;11: 307-14.

${ }^{27}$ Andersson L, Nilsson IM. AMCA (aminomethyl cyclohexane carboxylic acid, Cyklo-kapron) a potent haemostatic agent in urinary tract bleeding. Scand J Urol Nephrol 1969;3:169-76.

${ }^{28}$ Kjellman H. Synthetic antifibrinolytics. In: Nilsson IM, ed. Haemorrhagic and Thrombotic Diseases. London: John Wiley, 1974:140-5.

${ }^{29}$ Carroll HJ, Tice D. The effects of epsilon-aminocaproic acid upon potassium metabolism in the dog. Metabolism 1966;15:449-57.

${ }^{30}$ Frank MM, Sergent JS, Kane MA, Alling DW. Epsilon aminocaproic acid therapy of hereditary angioneurotic edema. $N$ Engl J Med 1972;286:808-12.

${ }^{31}$ Korsan-Bengtsen K, Ysander K, Blohmé G, Tibblin E. Extensive muscle necrosis after long-term treatment with aminocaproic acid (EACA) in a case of hereditary periodic edema. Acta Med Scand 1969;185: 341-6.

${ }^{32}$ Wysenbeek AJ, Sella A, Blum I, Yeshurun D. Acute delirious state after $\epsilon$-amino caproic acid administration. Clin Toxicol 1979;14:93-5.

${ }^{33}$ Eneroth G, Grant CA. Epsilon aminocaproic acid and reduction in fertility of male rats. Acta Pharm Suec 1966;3:115-22.

${ }^{34}$ Vermylen J, Verhaegen-Declercq ML, Verstraete $M$, Fierens F. A double-blind study of the effect of tranexamic acid in essential menorrhagia. Thromb Diathes Haemorrh 1968;20:583-7. 
${ }^{35}$ Hedlund PO. Antifibrinolytic therapy with cyklokapron in connection with prostatectomy. Scand $J$ Urol Nephrol 1969;3:177-82.

${ }^{36}$ Naeye RL. Thrombotic disorders with increased levels of antiplasmin and antiplasminogen. $N$ Engl J Med $1961 ; 265: 867-71$.

37 Rydin E, Lundberg PO. Tranexamic acid and intracranial thrombosis. Lancet 1976;2:49.

${ }^{38}$ Davies D, Howell DA. Tranexamic acid and arterial thrombosis. Lancet 1977;1:49.

${ }^{39}$ Becker J, Borgström S. Incidence of thrombosis associated with epsilon-aminocaproic acid administration and with combined epsilon-aminocaproic acid and subcutaneous heparin therapy. Acta Chir Scand 1968;134:343-?.

${ }^{40}$ Gordon-Smith IC, Hickman JA, El Masri SH. The effect of the fibrinolytic inhibitor epsilon-aminocaproic acid on the incidence of deep-vein thrombosis after prostatectomy. Br J Surg 1972;59:522-4.
41 Vinnicombe J, Shuttleworth KED. Aminocaproic acid in the control of haemorrhage after prostatectomy: a controlled trial. Lancet 1966;1:230-4.

42 Hedlund PO. Postoperative venous thrombosis in benign prostatic disease. A study of 316 patients, using the ${ }^{125}$ I-fibrinogen uptake test. Scand J Urol Nephrol (Suppl) 1975;27.

${ }^{43}$ Åstedt B, Pandolfi M, Nilsson IM. Quantitation of fibrinolytic agents released in tissue culture. Experientia 1971;27:358-9.

${ }^{44}$ Stark SN, White JG, Langer L, Jr, Krivit W. Epsilonaminocaproic acid therapy as a cause of intrarenal obstruction in haematuria of haemophiliacs. Scand $J$ Haematol 1965;2:99-107.

${ }^{45}$ Gobbi F. Use and misuse of aminocaproic acid. Lancet 1967;2:472-3.

${ }^{46}$ Saldeen T. Quantitative determination of intravascular coagulation in the lungs of experimental animals. Scand J Haematol 1969;6:205-15. 